\title{
DOHAD and early pubertal timing
}

\author{
Ken K. Ong \\ From 8th APPES Biennial Scientific Meeting \\ Darwin, Australia. 29 October - 1 November 2014
}

Age at menarche varies widely between girls, is estimated to be highly heritable and is associated with long-term health outcomes, such as obesity and type 2 diabetes. Earlier pubertal maturation in boys and girls links rapid postnatal growth weight gain to later life metabolic and cardiovascular disease [1,2]. Genome-wide association studies (GWAS), which genotype hundreds of thousands of common genetic variants located across the entire genome, have been successful in identifying many specific genetic determinants of pubertal timing and these findings have informed the mechanisms that link earlier pubertal timing to increased risks of disease. The genetic signals indicate that both obesity-related and obesityindependent mechanisms may link pubertal timing to insulin sensitivity and diabetes risk.

Our earlier findings [3] in the ReproGen international GWAS consortium identified substantial overlap between loci associated with menarche and those associated with body mass index, as had been predicted by analyses of data from twins, and in keeping with recognised associations between infancy and childhood weight gain and pubertal timing, and in turn between pubertal timing and obesity in adult life. However, the locus with the strongest individual effect size is in the gene LIN28B, which regulates microRNA processing and also insulin sensitivity. Our recent larger studies indicate further mechanisms that may link puberty timing to diabetes risk, and also suggest pubertal timing as a possible postnatal development target for the evolution of genomic imprinting [4].

Published: 28 April 2015

\section{References}

1. Lakshman R, Forouhi NG, Sharp SJ, Luben R, Bingham SA, Khaw KT, Wareham NJ, Ong KK: Early Age at Menarche Associated with Cardiovascular Disease and Mortality. J Clin Endocrinol Metab 2009, 94(12):4953-4960.
2. Elks CE, Ong KK, Scott RA, van der Schouw YT, Brand JS, Wark PA, et al: Age at menarche and type 2 diabetes risk: the EPIC-InterAct study. Diabetes Care 2013, 36(11):3526-3534.

3. Elks CE, Perry JR, Sulem P, Murabito J, Ong KK, Murray A, et al: Thirty new loci for age at menarche identified by a meta-analysis of genome-wide association studies. Nature Genetics 2010, 42(12):1077-85.

4. Perry JR, Day F, Elks CE, Sulem P, Stefansson K, Murabito J, et al: Parent-oforigin-specific allelic associations among 106 genomic loci for age at menarche. Nature 2014, 514(7520):92-97.

doi:10.1186/1687-9856-2015-S1-012

Cite this article as: Ong: DOHAD and early pubertal timing. International Journal of Pediatric Endocrinology 2015 2015(Suppl 1):012.
Submit your next manuscript to BioMed Central and take full advantage of:

- Convenient online submission

- Thorough peer review

- No space constraints or color figure charges

- Immediate publication on acceptance

- Inclusion in PubMed, CAS, Scopus and Google Scholar

- Research which is freely available for redistribution
() Biomed Central 